\title{
13. Reproducing the Techno-Nuclear State in Washington State and Ontario
}

\author{
Linda Marie Richards
}

Linda Marie Richards has studied nuclear history, human rights, environmental justice, and nonviolence for over thirty years while teaching all ages in the streets and the classroom. She has a PhD in History of Science and teaches in Oregon State University's School of History, Philosophy, and Religion. Her current book project, Human Rights and Nuclear Wrongs asks how nuclear weapons and technology shaped what we think of as human rights.

Linda.Richards@oregonstate.edu

On a spring day in 1994, the endearingly gruff Dr. Jay Mullen thrust a heavy archive box at me. "You have a degree in science," he demanded, "figure this out!"

I sat down and started to fumble through the box, tentatively pulling out a study or two, seeing them stamped declassified. "You want me to understand the scientific papers?" I stammered, stunned.

"Yes," he said, "make it make sense. Just take the whole damn box. I don't want it in my office anymore. Get it out of here," he barked.

I didn't drive so I carried the box home. I walked with it cradled in my arms; then upon each shoulder for more than a mile and a half while invoking some higher power to be able to decipher the papers in the box. I earned the burden many years before when I first recognized Dr. Mullen's mark of being a Downwinder. From my first day as his student at then Southern Oregon State College, the scar around Dr. Mullen's neck glared ominously at me. 
I adored everything else about him. He mesmerized with his stories too farfetched to be real. Such as he used to be a CIA agent, worked in eastern Africa in the 1970s, and was friendly with and spied on Idi Amin. Turns out, it was all true. ${ }^{1}$ One day in class he told a story about how he had been paralyzed and his thyroid removed as a teen. ${ }^{2}$

I had to blurt out "I've seen that scar many times." He asked, "really?"

His eyes went wide. He asked me to come to his office after class. There, I told him about my vows, first to end war when I was a child and my father was in Vietnam. Then, in 1986, hoping that abolishing nuclear weapons would build enough trust to actually someday end war, I walked on "The Great Peace March for Global Nuclear Disarmament," a nine-and-ahalf-month protest from LA to DC. Walking, I learned about the damage nuclear weapons can do at each step, from mining and milling to production, testing, use, and storage. I promised the Navajo, Hopi and Pueblo elders, including Roberta Blackgoat and too many widows of uranium miners, that I would share their stories of contamination, loss, and death with everyone I met. The only vow I could keep.

"Many different types of people, with a scar like yours, told me their stories," I said.

Their thyroid had been removed because the radioactive iodine emitted by fallout and nuclear fission products can concentrate in the gland. I reached in my backpack and pulled out my biological illustration class assignment which was to draw a "web of life." In my macabre sketch, thick black ink arrows, dots and specks tried to convey an anti-web caused by invisible radiation. lodine 131, radionuclides and rays showered the soil and growing plants, breaking 
bonds, only to be eaten by cows, contaminating their bodies. From there, a raised glass of milk poured into a thyroid.

Nuclear technology can do all kinds of unexpected harm. I told Dr. Mullen about how my uncle had been decorated for his heroism in Korea but he lived tortured by his memory of the atomic bombs he was forced to march through, sterilized despite the assurances. My cousins were adopted. Dr. Mullen's office had turned dark like a tomb. Packed with books and papers, it was the quintessential professor's office but now filled with unease.

I finally ventured: "Where did you grow up? Did you live near the Nevada Test Site?"

"When I was a little boy, I lived in Farragut Naval Station, in Idaho," he said.

"You're a Hanford Downwinder. They made plutonium there!" I exclaimed point-blank, unequivocal.

After hearing my own voice sound immutable, like concrete, I was mortified. It took Jay Mullen thirty years to finally understand why a healthy fit nineteen-year-old football player would not be able to move one morning. But in seconds, I watched it all click plainly on his pained face. When children learn to read, there is a light in their eyes as the letters finally make words and the words align to suddenly made sense, a visible gasp shares their awe. I was the midwife of his curse.

We sat quietly in the irretrievable pronouncement of it. 
I tried to undo it, to mumble it away. "I am sorry, I am probably wrong. There is no way the radiation from Hanford could have ever gone that far, nearly two hundred miles northeast?" We did not fully understand the magnitude of the pollution and the releases yet.

Six or so years later, Dr. Mullen shoved the box at me. Until that moment, science gave my life meaning and order; so unlike the rest of the world. His box was crammed tight with Atomic Energy Commission and nuclear contractors' declassified radiation studies released in 1986 as part of a FOIA request. These were mixed in with other studies and documents he had collected while strategizing with other Downwinders for medical care or just some semblance of truth or amends. ${ }^{3}$

But I could never decrypt the papers in the box, week after week. The language I loved of science, organic biochemistry and molecular reactions left me mute. Health physics was inchoate. It mathematized risk by inserting unknowns and assumptions into calculus, using derivatives and probabilities to look certain. After my boyfriend died suddenly from a heart arrhythmia in 1994, Dr. Mullen mournfully came to my house to pick up the box. "I am sorry," I said. “I can't keep this box of papers anymore. I can't make this science make sense like science is supposed to. It is all chance with uncertainties, like gambling." Like life and death.

I suspected radiation health safety was a puzzle on purpose unless you were disciplined as a health physicist. But then, your training might obscure other ways of seeing. ${ }^{4}$ Antoine Lavoisier argued chemistry was not a science until it could be clearly explained to anyone. Like him, erudite scientist Linus Pauling argued the Atomic Energy Commission view of radiation 
safety was more a construction of ignorance, long before the History of Science had the word "agnotology."5

Pauling extensively annotated his copy of the 1957 Congressional Hearings, now in the Oregon State University Special Collections and Archives Center. Pauling highlighted health physicist Lauriston Taylor's testimony. Taylor stated: “Any radiation exposure received by man must be accepted as harmful." Then on the same page, Taylor defined radiation protection standards as "the limits of radiation exposure which the individual or whole population can be exposed without encountering risks incommensurate with the benefits to be expected from its use." ${ }^{6}$ This dichotomy disassembles the ideas of what safety means.

A counternarrative to radiation safety science is buried in the bodies of those exposed like Dr. Mullen and my Uncle Vic. It is in the illnesses, diseases, cancers, birth defects, spontaneous abortions and sterility; the mental anguish, suffering and the betrayal of the word "safe." Documents at the UN in agencies like the IAEA and WHO show how a regulatory threshold for intergenerational contamination was accepted, disciplined, inscribed and globally reproduced by UN Technical Experts and academics standardizing practices, education and radiation legislation. The harms of radiation have legally multiplied in time and space.

A vast nukescape from uranium mining is in Elliott Lake.

This is the traditional home to the Serpent River First Nations in Ontario. A rocky outcropping, where Serpent River First Nation used to hold ceremonial dances, is stained red by heavy metal toxicity. Most of the other danger is imperceptible. To lose sacred space, sturgeon 
fish and the eighteen lakes that are now "uranium tailings management areas," is unfathomable. Twelve former mines in the area, according to the executive summary of the Canadian Nuclear Safety Commission report (January 2015) caused "irreversible damage" to lands and lakes. However, the Commission also determined that radium, uranium and other toxins materials "are generally below" the Canadian water safety guidelines, and therefore, the Commission states confidentially: "The general public can safely consume fish from the lakes in the region." 7

My science degree cannot make this type of risk make sense as "safely." 


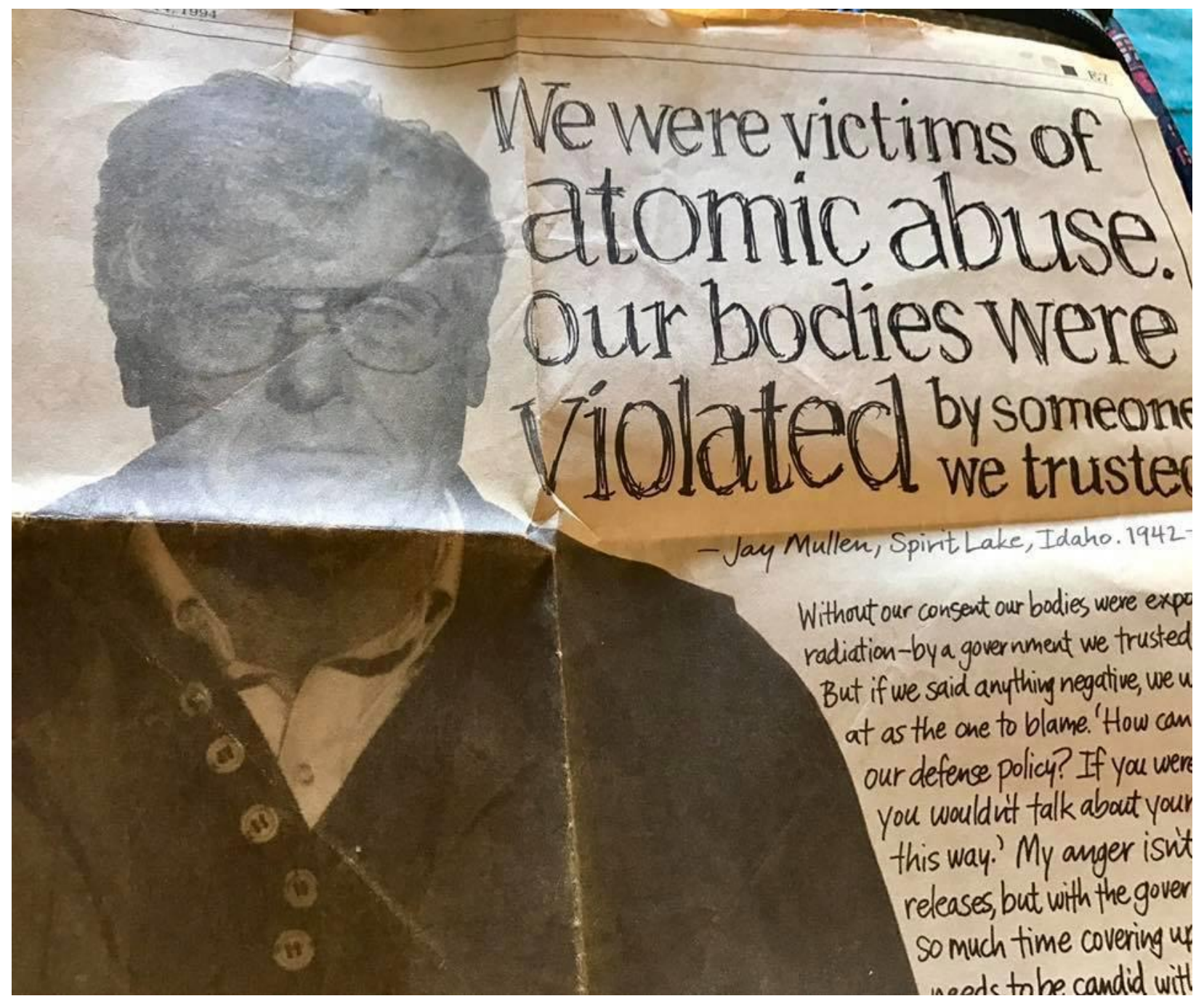

Figure 12. This photo of the late Dr. Jay Mullen is just a part of one of the many full-page newspaper advertisements made by Hanford Downwinders to alert the public about Hanford's legacy of harm from the secret production of plutonium. Mullen displayed several of the ads featuring different Hanford Downwinders during the annual Hiroshima Nagasaki Vigil on the Ashland, Oregon downtown plaza, where he occasionally lectured to educate the public about the harms of propaganda, secrecy and nuclear weapons. (Jay Mullen Poster, Series 1: Donor Materials, Donation \#670, Hanford Health Information Archives Collection, AR69-2-0-21, Washington State Archives, Office of the Secretary of State, Olympia, WA. Image is in the public domain.)

${ }^{1}$ Rudy Maxa, “Our CIA Man in Idi Amin's Uganda," The Washington Post, January 6, 1980, https://www.washingtonpost.com/archive/lifestyle/magazine/1980/01/06/our-cia-manin-idi-amins-uganda/264b533a-c029-46fe-8e66-a2e44f9d7a80/. 
2 See Jay Mullan's oral history in Trisha Pritikin, The Plaintiffs: Voices from the Fight for Atomic Justice (Lawrence: University Press of Kansas, 2020), 49-55.

${ }^{3}$ Kinsella, William J. and Jay Mullen, "Becoming Hanford Downwinders: Producing Community and Challenging Discursive Containment," in Nuclear Legacies: Communication, Controversy and the U.S. Nuclear Weapons Complex, eds. Bryan C. Taylor, William J. Kinsella, Stephen P. Depoe and Maribeth S. Metzler (New York: Lexington Books, 2007), 73-108.

${ }^{4}$ National Science Foundation Award \#1734618 supported OSU to collect oral histories from Hanford Downwinders involved in litigation, scientists, and others exposed to radiation in order to give history and science a fuller picture. Learn more at the Downwinders Project Blog, http://blogs.oregonstate.edu/downwinders/

${ }^{5}$ Robert N. Proctor and Londa Schiebinger, eds., Agnotology: The Making and Unmaking of Ignorance (Stanford University Press, 2008).

${ }^{6}$ US Congress, Joint Committee on Atomic Energy, The Nature of Radiative Fall-out and its Effects on Man, Hearings before the Joint Committee on Atomic Energy, 85th Cong., 1st sess., vol 2. (1957), 828.

https://books.google.com/books?id=zRSOsetPM2EC\&printsec=frontcover\&source=gbs ge sum mary $\mathrm{r} \& \mathrm{cad}=0 \# \mathrm{v}=$ onepage $\& \mathrm{q}=\% 22 \mathrm{Any} \% 20$ radiation $\% 20$ exposure $\% 20$ received $\% 20 \mathrm{by} \% 20 \mathrm{man}$ \%20must\%20be\%20accepted\%20as\%20harmful\&f=false.

${ }^{7}$ Canadian Nuclear Safety Commission, History of Uranium Mining in the Elliot Lake Region of Ontario and Associated Effects on Water Quality and Fish Intended for Human Consumption, January 2015, i, document number: 308 NAT32_VA 6211-08-012 http://142.44.245.8/sections/mandats/uranium-enjeux/documents/NAT32 VA.pdf and in possession of the author. 